\title{
A study on relationship between earnings management and operating cash flows management: Evidence from Tehran Stock Exchange
}

\author{
Bahman Banimahd $^{\mathrm{a}^{*}}$ and Mina Jalali Aliabadi ${ }^{\mathrm{b}}$
}

${ }^{a}$ Department of Accounting, University of Economic Sciences, Tehran, Iran ${ }^{b}$ M.Sc. Student, Department of Accounting, University of Economic Sciences, Tehran, Iran

\section{H R O N I C L E}

\section{Article history:}

Received January 10, 2013

Received in revised format

10 April 2013

Accepted 12 May 2013

Available online

May 142013

Keywords:

Earnings management

Operating cash flows management

Financial risk and loss

\begin{abstract}
A B S T R A C T
\end{abstract}
This study investigates the impact of earnings management on operating cash flows management over the period 2004-2011 using the information of 119 firms listed on the Tehran Stock Exchange. Results indicate that there is a meaningful relationship between earnings management and operating cash flows management. In other words, earnings management creates and shapes operating cash flows management. In addition, after controlling for the loss reporting, firm size and firm's financial risk, the results show that there was a relationship between loss reporting and firm size with the cash flows management. When firms report loss, then operating cash flows increases. Finally, operating cash flows decreases when firm size increases. However, our survey does not provide any evidence to believe there is any relationship between financial risk and cash flows management.

\section{Introduction}

Earnings and operating cash flows are complementary indexes on corporate performance. Firms' analysts, investors, creditors, managers and other users of the financial information pay more attention to use earnings and operating cash flows (OCF) to analyze and to forecast firm performance. Based on different characteristics of corporates, OCF and earnings have various implications for future firm performance. However, recent studies indicate that misreporting of earnings have raised concerns that managers exercise discretion in financial reporting and try to manage OCF. These studies suggest that misreporting of earnings may cause misreporting OCF. This is a challenge to determine OCF management and earnings management. However, there are still insufficient studies on how firms manage reported OCF (Lee, 2011). 
This study investigates the effect of earnings managements on operating cash flows by investigating whether earnings management inflates operating cash flows or not. Lack of sufficient studies about relationship between earnings managements and operating cash flows management as well as increasing on the number of listed firms in Iranian capital market have created a motivation to conduct this study. This study contributes to the literatures as follows:

First, result of the research can improve the theoretical fundamentals of previous studies about earnings management and operating cash flows management in developing countries. Second, there are some evidences, which indicate the relationship between earnings management and OCF management. This issue, as a scientific finding, can provide useful information for the Iranian capital market regulatory oversight board. Third, the results of this paper can propose new ideas to conduct new studies in OCF management and earnings management.

The main question of this research is to understand on how earnings management influences OCF management. In addition, the primary goal is to provide the determinants of OCF management for firms' analysts, investors, creditors, managers and other users of the financial information, regulators of accounting and stock exchange organization. In the following, literature review, variables and research questions are investigated.

\section{Literature review}

Earnings management is selection of accounting policies to decrease or increase the reported earnings by managers so that mangers could achieve their objectives. The managers may reduce earnings when profitability is unusually high and maximize earnings when profitability is unusually low. The management compensation hypothesis indicates that managers may increase their compensations by selecting accounting policy. Hence, under this hypothesis, managers will attempt to maximize net income when net income influences their compensation. Political cost hypothesis also claims that there is an incentive to manage earnings by managers to decrease net income when a firm faces with political pressures (Yoon \& miller, 2002).

DeFond and Hung (2003) claimed that simultaneous use of cash flows and earnings were more useful to market participants to interpret earnings and stock valuation. They suggested that analysts are more likely to estimate cash flows when cash flows are useful in interpreting net income and assessing firm performance. Yoon and miller (2002) studied the relationship between the operating performances of Korean industrial firms and earnings management. They found that Korean industrial firms manage earnings. Their results showed that when operating performance was low, the firm managers had an incentive to select earnings-increasing forms.

According to Luo (2008) it is difficult for investors to assess a firm's future performance via current financial reporting of cash flows from operations, because it does not present individual sources of these cash flows. His research results show that the unusual individual cash flow items contain a significant incremental predictive ability for future cash flows. He also reported that current reporting of cash flows from operations could mislead investor about firms' cash generating abilities and proposed that investors could benefit from a more explicit presentation of cash flows from operations. Zhang (2009) investigated cash flow management in the Chinese firms, compared his results with some U.S. firms, and concluded that there was a positive relationship between cash flows management and earnings management. He showed that cash flow management behaviors in China were more prevalent than U.S. However, cash flow management around analyst cash flow forecasts was no more prevalent than that in the U.S. market was.

Lee (2012) showed that operating cash flows was distinct from earnings management and some firms could not manage operating cash flows because of accruals manipulation. He claimed that managers of firms resort the operating cash flows by classification and timing of accruals items. He determined 
four firm characteristics for inflating operating cash flows including financial distress, a long-term credit rating near the investment/non-investment grade cutoff, the existence of analyst cash flow forecasts, and higher associations between stock returns and CFO. The outcomes of this study indicated that firms could manage operating cash flows in an upward manner. Kothari et al. (2005) indicated that managers consider operating cash flows more important to external users than earnings when the firm is near financial distress. They claimed that operating cash flow information is very important in assessing credit and bankruptcy risks.

Chung et al. (2009) investigated the relationship between earnings management and equity liquidity and indicated that greater earnings management could signal higher adverse selection costs. Their results indicated that firms with higher earnings management suffered from lower equity liquidity. Iatridis and Kadorinis (2009) found that firms with low profitability and high leverage are more likely to engage with earnings management. They also explained that firms should have a desirable debt ratio for debt covenants employ earnings management practices. Their results confirmed that firms with voluntary accounting disclosures appeared to be less inclined to make use of earnings management.

Nikoomaram et al. (2012) indicated that some Iranian firms engage in earnings management. Their findings also demonstrated that firms with higher debt ratio, larger size, more changes of CEO and higher rate of return on assets are more likely to engage in earnings management while there was no evidence of taxation effect on earnings management. Habib (2008) investigated the relative and incremental information content of earnings and cash flows in New Zealand and explained that earnings had higher explanatory power than cash flows and both earnings and cash flows had incremental information content for stock returns. Miranda-Lopez and Nichols (2012) explained that the majority of participants in the U.S. depend on earnings while the majority of participants in Mexico depend on cash flows. However, results were mixed for participants using earnings, since they documented a higher chance of forecasting errors for participants in both countries when using earnings rather than cash flows in their calculations for the failure of these participants to adjust earnings for depreciation.

\section{Sample selection and research method}

Our sample covers listed firms on the Tehran Stock Exchange (TSE) over the period 2004-2011. The sample selection criteria are as follows,

A. The end of fiscal year is March 21.

B. Data is available at least for seven years in period 2004 to 2011, and

C. The company is not loss frequently for three years.

Given to above criteria, 119 companies were selected from different industries.

Research method is correlation and we use a linear regression method for research questions testing. Research data have extracted from financial statements of the listed firms on the Tehran Stock Exchange available in its electronic database and there were 955 observations.

\section{Research questions}

Given theoretical fundamentals and literature review, the following questions are stated for this study,

Question 1: Is there any significant relationship between earnings management (EM) and OCF management? 
Question 2: Is there any significant relationship between loss reporting and OCF management?

Question 3: Is there any significant relationship between financial risk and OCF management?

\section{Research variables}

In this study, independence variables are earnings management, loss reporting, firm size and financial risk. Dependent variable is also OCF. The measurement of all variables is described in the following.

loss Reporting: A dummy variable shown by $0 / 1$. When a firm report a loss the value will be set 1 ; and otherwise it is 0 .

Financial Risk: This variable is equal to the ratio of total debt on total assets ratio.

Firm Size: This variable is calculated based on the natural logarithm of the total assets.

Operating Cash Flows Management: This variable is measured based on Eq. (1). This model is used by Lee (2011) to estimate operating cash flows management.

$O C F_{i t} / T A_{i t-1}=a_{0}+a_{1}\left(1 / T A_{i t-1}\right)+a_{2}\left(\right.$ sale $\left._{i t} / T A_{i t-1}\right)+a_{2}\left(\Delta\right.$ Sale $\left._{i t} / T A_{i t-1}\right)+\varepsilon$

where:

$$
\begin{aligned}
& O C F_{i t}=\text { operating cash flows, } \\
& T A_{i t-I}=\text { total assets at the beginning of the period, } \\
& \text { Sale }=\text { firm's sale at the period, } \\
& \triangle S a l e=\text { change in sales during period, } \\
& \varepsilon=\text { error term for firm } i \text { in year } t
\end{aligned}
$$

We use the parameter estimates from Eq. (1) to measure unexpected OCF is the difference between actual and expected OCF as OCF management.

Earnings Management: this variable measure by Eq. (2). This model used by Kothari et al. (2005) to estimate earnings management.

$$
T A_{i t}=a_{0}+a_{1}\left(\Delta \operatorname{Rev}_{i t}-\Delta \operatorname{Rec}_{i t}\right)+a_{2} P P E_{i t}+a_{3} R O A_{i t}+\varepsilon_{i t}
$$

where:

TA $=$ total accruals for firm $i$ in year $t$;

$\mathrm{A}_{\mathrm{it}-1}=$ total assets for firm $i$ in previous year;

$\Delta \mathrm{REV}_{\mathrm{it}}=$ change in revenues for firm $i$ in year $t$;

$\Delta \mathrm{Rec}_{\mathrm{it}}=$ change in accounts receivables for firm $i$ in year $t$;

$\mathrm{PPE}_{\mathrm{it}}=$ gross property, plant, and equipment for firm $i$ in year $t$

$\mathrm{ROA}=$ net profit to total assets ratio

$\varepsilon_{\text {it }}=$ error term for firm $i$ in year $t$.

We estimate the parameters using Eq. (2) to measure unexpected total accruals, which is the difference between actual and expected TA as earnings management. We control the effect of industry to estimate earnings management and OCF management. We also control the effect of industry and year effects on relationship between independent variables and dependent variable. 


\section{Results}

Descriptive statistics of the study are presented in Tables 1 and Table 2. Table 1 shows that the average of earnings management and operating cash flows are close to each other. Table 2 also shows that loss reporting by firms increased in 2010 and 2011. Regression results in Table 3 show that there was a significant relationship between earnings management, loss reporting and firm size with the OCF management. This Table also indicates that there was no significant relationship between financial risk and OCF management.

Table 1

Descriptive Statistics

\begin{tabular}{lcccl}
\hline & Financial Leverage & OCF & EM & Total Assets \\
\hline $\mathrm{N}$ & 955 & 955 & 955 & 955 \\
$\mathrm{Mean}$ & 0.667 & -0.0004 & 0.0015 & 2465677.5 \\
Median & 0.661 & -0.0102 & 0.0046 & 372218.79 \\
Standard Deviation & 0.317 & 0.1423 & 0.0957 & 26570471.278 \\
\hline
\end{tabular}

Table 2

Descriptive Statistics

\begin{tabular}{|c|c|c|c|}
\hline Year & Non-Loss Reporting Firms & Loss Reporting Firms & Total \\
\hline 2004 & 117 & 3 & 120 \\
\hline 2005 & 115 & 5 & 120 \\
\hline 2006 & 118 & 2 & 120 \\
\hline 2007 & 118 & 2 & 120 \\
\hline 2008 & 118 & 2 & 120 \\
\hline 2009 & 108 & 3 & 120 \\
\hline 2010 & 117 & 12 & 120 \\
\hline 2011 & 99 & 16 & 115 \\
\hline Total & 910 & 45 & 955 \\
\hline
\end{tabular}

Table 3

Regression Results

\begin{tabular}{lllll}
\hline Variables & $\beta$ & T- Statistics & P-Value & VIF \\
\hline Constant & 0.134 & 0.911 & 0.313 & - \\
Earnings Management & 0.099 & 2.071 & 0.039 & 1.531 \\
Loss Reporting & 0.061 & 2.841 & 0.005 & 1.661 \\
Financial Risk & -0.018 & -0.008 & 0.183 & 1.857 \\
firm size & -0.005 & -5.352 & 0.000 & 2.136 \\
\hline $\mathrm{F}=1.816 \quad$ P-Value $=0.000 \mathrm{R}^{2}=12.3 \%$ & $\mathrm{DW}=1.583$ & &
\end{tabular}

\section{Summary and conclusion}

Descriptive statistics show that the average of earnings management and operating cash flows are close together during the research period. The results also show that loss reporting by firms increased in 2010 and 2011. In addition, there was a direct and positive relationship between earnings management and OCF management. These results confirm that when a firm report loss then OCF management would be increased. Firm size has had a negative relationship with OCF management. However, research evidences showed that there had been no relationship between financial risk and cash flows management. These results suggest that the firms would be able to manage OCF by misreporting earnings. Therefore, we suggest to firms' analysts, investors, creditors and regulators of 
accounting to use the findings of this study for their analysis and programs. It is proposed to compare OCF management with other earnings management metrics. We also suggest to investigate CFObased metrics in executive compensation.

\section{References}

Chung, H., Sheu, H. J., \& Wang, J. L. (2009). Do firms' earnings management practices affect their equity liquidity?. Finance research letters, 6(3), 152-158.

DeFond, M. L., \& Hung, M. (2003). An empirical analysis of analysts' cash flow forecasts. Journal of Accounting and Economics, 35(1), 73-100.

Habib, A. (2008). The role of accruals and cash flows in explaining security returns: evidence from New Zealand. Journal of international accounting, auditing and taxation, 17(1), 51-66.

Iatridis, G., \& Kadorinis, G. (2009). Earnings management and firm financial motives: A financial investigation of UK listed firms. International Review of Financial Analysis, 18(4), 164-173.

Kothari, S. P., Leone, A. J., \& Wasley, C. E. (2005). Performance matched discretionary accrual measures. Journal of accounting and economics, 39(1), 163-197.

Lee, L. F. (2011). Incentives to inflate reported cash from operations using classification and timing. The Accounting Review, 87(1), 1-33.

Luo, M. (2008). Unusual operating cash flows and stock returns. Journal of Accounting and Public Policy, 27(5), 420-429.

Miranda-Lopez, J. E., \& Nichols, L. M. (2012). The use of earnings and cash flows in investment decisions in the US and Mexico: Experimental evidence. Journal of International Accounting, Auditing and Taxation, 21, 198-208.

Nikoomaram, H., Banimahd, B., \& Shokri, A. (2012). An empirical analysis of earnings management motives in firms listed on Tehran Stock Exchange. Journal of Basic and Applied Scientific Research 2(10), 9990-9993.

Yoon, S. S., \& Miller, G. A. (2002). Cash from operations and earnings management in Korea. The International Journal of Accounting, 37(4), 395-412.

Zhang, R. (2009). Cash flow management in the Chinese stock market: An empirical assessment with comparison to the US Market. Frontiers of Business Research in China, 3(2), 301-322. 